Journal of Islamic Economics Perspectives, Volume 3. Issue l (2021)

\title{
THE ENVIRONMENTAL PERFORMANCE OF CIVIL EMPLOYEES IN SIDOARJO DISTRICT BASED ON ETHICAL LEADERSHIP, ETHICAL CLIMATE, AND CLIMATE STRENGTH
}

\author{
Tatag Herbayu Latukismo \\ Universitas Krisnadwipayana Jakarta \\ tatag@unkris.ac.id \\ Ayoub Gougui \\ University Utara Malaysia \\ Ayoub_gougui@oyagsb.uum.edu.my
}

\begin{abstract}
Abid Farid
Institute of Commerce and Business Administration Layyah Pakistan

Abidfarid 2154@gmail.com
\end{abstract}

\begin{abstract}
Ethical climate in several studies differently suggests likely to have a clear understanding of developing ethical behavior to be expected to their organization. Contribution to work behavior as evidence and indicating among employees tend to lead by ethical code. Hierarchy way from highest to the lowest position must lead to work together and construct developing an ethical climate. Thus, this conservative way could be the efficient and most expected value on the organization. In this research, the ethical climate is implemented by the environmental performance results of the civil servant in the Sidoarjo district. This research-based on three variable concepts by each ethical climate, ethical strength, and ethical leadership. This research utilizes a qualitative comparative method with collecting data as a literature study. The Index Satisfaction of Civil Servant in Sidoarjo District as the prime references compared to the issues and variables.
\end{abstract}

\section{INTRODUCTION}

This study describes the relationship between ethical climate and firm-level of ethical strength in a comparative analysis. The results performance of civil servants in Sidoarjo district in addition obtaining measures of ethical climate and ethical strength from sources, current research aims at implementing ethical climate research, intending to examine the moderating role of climate forces associated between ethical climate and climate forces. 
Climate power is defined as the degree which members of a work unit or organization agree on their perceptions of the workplace climate (Ogbonna \& Harris, 2000). In organized climate research, climate forces have often been identified as moderating the relationship between climate perceptions and organizational outcomes (Tuma, J. M., \& Pratt, J. M., 1982).

Despite the importance of climate forces, almost no research in the domain of business ethics has investigated its moderating effect on ethical climate. This is a critical comission as many studies have shown that even pairing rates can give different results depending on climatic forces. In particular, climate power is even more relevant to ethics research because employees have the same perception of their organization's ethical climate. They experience less ambiguity paying attention to what is right and wrong in the organization and consequently engage in more ethical or prosocial behavior (Shin, 2012). In this sense, it is imperative to examine the role climate forces play in the relationship between ethical climate and ethical forces.

Employees in public services are regulated based on Undang-Undang Nomor 25 Tahun 2009 concerning public services. Based on Community Satisfaction Index data for civil servants in Sidoarjo District as an indicator of the level of the Public Service Provider Unit in Government Agencies to improve again in the future Urgency is needed in order to encourage economic and social growth as an impact on the welfare of society. Every year, the quality of public services (civil servants in Sidoarjo District) strives for significant improvement which are classified into various groups.

In summary, the aims of this study are twofold namely, as mentioned earlier, the first objective is to implement the relationship between ethical leadership and ethical climate. The proposition research developed in this study is empirically tested using large-scale data obtained from the performance reports of civil servants in Sidoarjo District.

\section{LITERATURE REVIEW}

\subsection{ETHICAL CLIMATE}

The ethical climate is a topic that has attracted a great deal of attention from business ethics researchers. Ethical Climate refers to the shared perceptions about policies, practices, and procedures, both formal and informal, of an organization. Ethical climate is considered a type of organizational climate that reflects employees' perceptions of ethical policies, practices, and procedures organization (DeConinck, 2011a). Although there is evidence that perceptions of organizational climate within an organization and subunits or work groups may have different climates, in this study, ethical climate is conceptualized as an organizational-level construct that represents resentment for employees' shared perceptions of corporate climate ethics. Because the behavior of company employees is determined by the same company policies, procedures, and code of conduct, they tend to have the same performance perceptions of its ethical climate. Furthermore, a firm's ethical climate 
determines its ethical values and behavior and influences the ethics of its employees (Wimbush \& Shepard, 1994). Therefore, in ethical terms, employees tend to be more affected by the organizational climate than the climate of their work group.

The ethical climate is characterized by the number of organizations that exist from a variety of ethical climates. An ethical work climate in the organization is very important in the organization, because it is a big influence on the ethical behavior of employees. Efficiency of ethical climate becomes the perception of organizational practices and procedures that are embedded in the organization (Wimbush \& Shepard, 1994). The ethical work climate involves perceiving right or wrong in the work environment of the organization and establishing norm values. Includes employee commitment in the company or organization, emotional level to play a role and serve in his employees.

Ethics in the work climate is very important in organizations engaged in sales. Previous research has shown that the public has a low perception that the ethical standards of employees in the sales field are below average. Cartons in the field of sales face this situation in a roundabout way and it creates a dilemma paradox in ethics (DeConinck, 2011). The dilemma paradox in practice often arises when employees working without direct supervision are very susceptible to behavioral and ethical neglect (DeConinck, 2011). Ethics in the work climate has pressure that has a quantity of quotas and has an impact on employees to behave unethically.

Ethics in a work climate is based on organizational identification derived from derivative social identification theory (DeConinck, 2011). Opinion that the classification of a group itself is based on social categories such as gender or religion. An individual will identify his other members based on similar characteristics and have something in common with one another. The nature of reactions like this will produce the same expression or behavior and create affinity groups belonging to the class order of ethical theory.

Although it is quite controversial whether ethical climate is a uni-dimensional or multi-dimensional concept, many scholars consider ethical climate to be a construction consisting of several sub-dimensions. The most well-known ethical climate classification is the Victor and Cullen's (1988) typology. Victor and Cullen (1988) classified Ethical Leadership and Ethical Climate While a number of studies have investigated the relationship between ethical climate and various work outcomes. Little effort has been directed to exploring the factors that shape or foster an ethical climate. However, ethical leadership is one of the factors identified as an antecedent of ethical climate. Ethical leadership is defined as "the demonstration of normatively appropriate behavior through personal actions and interpersonal relationships, and the promotion of these behaviors to followers through twoway communication, reinforcement, and decision making" (Brown \& Treviño, 2006, p. 120). Although scholars agree that leaders have an important role in shaping the ethical climate of 
a company (Grojean et al., 2004). There is not much empirical evidence regarding the relationship between ethical leadership and climate ethics. Given that top management strongly influences organizational and employee outcomes by articulating and communicating the vision and shaping organizational culture of the nation (Grojean et al., 2004). It is important to examine how leadership is ethics relates to the ethical climate of the company.

\subsection{ETHICAL LEADERSHIP}

Ethical leadership based in social learning theory in the form of antecedents of the meaning of ethical leadership itself (Brown \& Treviño, 2006). There are several individual characteristics of leaders that provide situational influences related to followers' perceptions of a leader as an ethical leader. The leader will be seen as an ethical leader by his followers and must demonstrate credibility in being a role model (Brown \& Treviño, 2006). This literature-based comparison between concepts and theories can identify that situational influences and individual characteristics can increase the attractiveness and credibility of leaders (Brown \& Treviño, 2006).

An individual in the process of becoming the leader of an organization is based on the notion that individuals will adapt to the social environment by observing (Brown \& Treviño, 2006). The values and behavior of individuals will be seen from the results of these observations because they inadvertently lead to the construction of these individual attitudes by means of ethical guidance. The ethical leader is most likely a source of guiding credibility in attracting attention and modeling an individual's behavior. The biggest attraction of an individual in the perception of leadership is power and status. The leadership will have the authority because it is able to occupy a position of relative status and is followed by the members of that organization. Of course this is subjective and needs to be morally characteristic.

Leadership ethics is very influential in the corporate environment. Charismatic style and giving value to organizational members are very important. However, the essence and essence of leadership can be lost. Issues like this eventually become a form of prevention by focusing on ethics in the form of ethical communication and leaving ethical messages (Brown \& Treviño, 2006). Ethical standards need to be applied highly and followed by members of the organization. The notion of punishment and reward is applied in the ethical leadership model as a reference in shaping the discipline of organizational members.

\subsection{CLIMATE STRENGTH}

Climate Strength becomes a variable in the climate of human resource development as a climate of interest and work involvement is linear and becomes a variable of results. The 
power of climate explaining the results of work by individuals and organizations is a comparison in organizational socialization (Schneider et al., 2002). Bliese and Halverson (1998) explain that climate power shows indirect linear effects through work involvement and the results of climate quality control. The quality of climate as a form of adequate representation of the climate of human resource development and its impact on work involvement.

In previous research, there was the development of climate strength variables. The strength of climate is in the psychological composition model (Schneider et al., 2002). The construction-to-concept mapping has similarities in organizational culture and cultural strength. Organizational culture and cultural forces are dispersed and conceptually focused in organizational research.

The forces of climate in developing constructively are situational. Mischel (1976) mentions that a strong situation is created based on the aspect of one's leadership in an organization. Events will occur and adapt in the decision making of an organization. This gives rise to appropriate behavior and implementation to react to an event. This applies to the opposite if individuals, especially leaders, are very weak in reviewing an event and their organizational situation will lead to inconsistencies in expectations and behavior

\section{METHOD}

\subsection{Types of Research}

This research use qualitative descriptive, which is an approach that emphasizes the inductive description by answering the problem formulation and argumentation components. This is expected to result in an active description and form conclusions under the influence of the variables (Bukhari, 2012). The research design is based on a comparative study model with the main reference as a literature study.

\subsection{Data Collection Method}

Data collection techniques utilize literature studies with primary references as primary and secondary sources as additional references (Sugiyono, 2012). Utilizing the data that has been provided by previous research by answering through formal descriptions to be combined with a comparative study model.

\subsection{Data Analysis Method}

The data analysis technique used a comparative study model. A comparative study model as a method by comparing an issue as a variable and an indicator with other variables (Bukhari, 2012). This relates to the causal component in explanative research but differs in the layout and causal analysis. This analysis technique is often used in social and political research because it makes use of literature studies (Bukhari, 2012).

This research is directed to find out whether there are differences between two or more groups in the aspects or variables studied. The research was carried out naturally, 
researchers collected data using measuring instruments. The results were statistically analyzed to look for differences between the studied variables. Comparative research can also provide reliable results, not only because it uses tested instruments but also because the groups being compared have the same or nearly the same characteristics.

\subsection{Argumentation}

The reason the researcher uses the comparative research problem in this study is the problem of comparison or the difference between the two variables based on the main reference from the results of the community satisfaction index in Sidoarjo District. Another important theoretical contribution of this research is that it is the first attempt to reveal the role of climate forces in business ethics research. While several studies have investigated the relationship between ethical climate and work outcomes, scholars have rarely explored the conditions in which this relationship is strengthened or weakened. The findings from this study indicate a moderate effect of climate forces on the relationship between ethical climate and climate forces.

There are significant implications for business ethics research, which in general suggests that a high-level ethical climate is associated with positive organizational and job outcomes. However, current studies show that the degree and strength of an ethical climate has a positive impact on outcomes. That is, the same level of ethical climate can be associated differently depending on whether company employees agree with their perceptions of ethical climate. These results suggest similar to a climate of justice (Colquitt et al. 2002). The perceptual agreement is also important in an ethical climate. When employees have the same perception of the company's ethical climate, they are likely to have a clear understanding of the ethical behavior expected of their organization. As a result, they contribute more to positive work behavior, as evidenced by the higher level of ethical climate. Besides, when climatic forces are high, perceptual congruence among employees tends to lead to behavioral transmission among them, which in turn leads to an increase in the human resources of civil servants in Sidoarjo District. Thus, climate forces tend to mobilize employee collective efforts toward positive work behavior.

\section{RESULT AND DISCUSSION}

\subsection{Results of Survey Data for Community Service Satisfaction Index Sidoarjo District Government}

Table 4.1: Service Satisfaction Index Sidoarjo area

\begin{tabular}{|c|c|c|c|c|}
\hline $\begin{array}{l}\text { Perception } \\
\text { Value }\end{array}$ & $\begin{array}{c}\text { UMKM Investment } \\
\text { Value }\end{array}$ & $\begin{array}{c}\text { UMKM } \\
\text { Innternal } \\
\text { Convention } \\
\text { Value }\end{array}$ & Results & $\begin{array}{c}\text { Public Sevices Unit } \\
\text { Status }\end{array}$ \\
\hline
\end{tabular}




\begin{tabular}{|c|c|c|c|c|}
\hline 1 & $1,00-2,5996$ & $25,00-64,99$ & D & Very Bad \\
\hline 2 & $2,60-3,064$ & $65,00-76,60$ & C & Bad \\
\hline 3 & $3,0644-3,532$ & $76,61-88,30$ & B & Good \\
\hline 4 & $3,5324-4,00$ & $88,31-100,00$ & A & Very Good \\
\hline
\end{tabular}

Source : Data for Community Service Satisfaction Index Sidoarjo District Government (Jitek, 2019)

The table shown the ratio of the interval value and the conversion of the Community Satisfaction Index (IKM) to Sidoarjo District Government employees in 2019. Based on the IKM interval value shows 1.00-2.5996 with the IKM conversion interval value 25.00-64.99, the quality of service rated D with a bad description. The IKM interval value is 2.60-3.064 with the IKM conversion interval value of 65.00-76.60 then the value of service quality is assessed as $\mathrm{C}$ with unfavorable information. Furthermore, the value of the IKM interval is 3.0644-3.532 with the value of the IKM conversion interval 76.61-88.30 then the value of service quality is B with good information. The value of the IKM interval is 3.5324-4.00 and the value of the IKM conversion interval is 88.31-100.00, then the value of service quality is A with a description of the overall performance of the service unit is very good.

Table 4.2: Index Satisfaction of Civil Servant

\begin{tabular}{|c|l|c|c|}
\hline \multirow{2}{*}{ Element } & \multicolumn{2}{|c|}{2019} \\
\cline { 3 - 4 } & \multicolumn{1}{|c|}{ Service Element } & $\begin{array}{c}\text { Service } \\
\text { Element } \\
\text { Value }\end{array}$ & $\begin{array}{c}\text { Service } \\
\text { Result }\end{array}$ \\
\hline 1 & Ease of Service Procedures & 3,447 & B \\
\hline 2 & Compliance with Requirements & 3,584 & A \\
\hline 3 & The presence of a Service Officer & 3,622 & A \\
\hline 4 & Discipline of Service Officers & 3,578 & A \\
\hline 5 & Ability of Service Officers & 3,567 & A \\
\hline 6 & Service Officer Speed & 3,521 & B \\
\hline 7 & Justice Service Officer & 3,584 & A \\
\hline 8 & Courtesy of Service Officers & 3,556 & A \\
\hline 9 & Officer Friendliness & 3,543 & A \\
\hline 10 & Punctuality & 3,545 & A \\
\hline 11 & Environmental Convenience & 3,537 & A \\
\hline 12 & Environmental Safety & 3,589 & A \\
\hline 13 & Availability of Facilities and Infrastructure & 3,548 & A \\
\hline 14 & Conditions of Facilities and Infrastructure & 3,581 & A \\
\hline
\end{tabular}




\begin{tabular}{|l|l|c|c|}
15 & The handling of complaints & 3,509 & $\mathrm{~B}$ \\
\hline 16 & Result Accuracy & 3,519 & $\mathrm{~B}$ \\
\hline & IKM Value & 3,552 & $\mathrm{~A}$ \\
\hline
\end{tabular}

Source : jitek 2019

In this table, if classified on the value of service quality, starting with the lowest value, namely $\mathrm{B}$ and marked in red, is the ease of service procedures, handling integration, and accuracy of results. Furthermore, the quality value written as A is service officer discipline, service officer ability, speed of completion, service officer fairness, service officer politeness, officer friendliness, punctuality, and environmental comfort. The A value marked in blue is compliance with requirements, the presence of service personnel, and environmental safety.

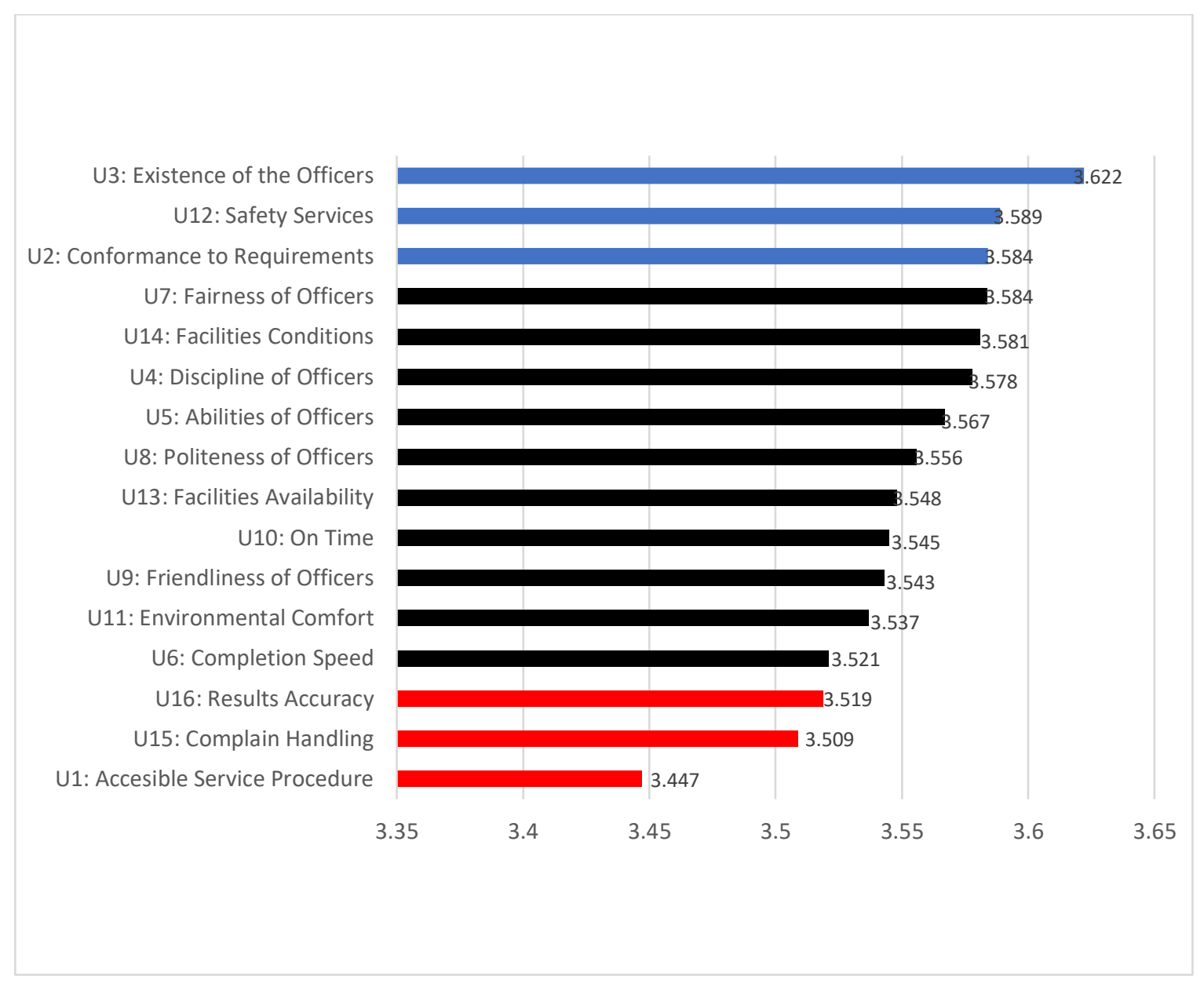

Figure 1: Index Utility of Civil Servants (Jitek, 2019)

Based on the three tables described and claims made by the Sidoarjo District with an index of 3.552, it is very good. The elements described are based on service officer data to 
get the highest satisfaction index. However, it needs to be criticized that the accuracy of results, handling of complaints, and ease of service procedures are still weak.

\subsection{Comparative Analysis}

These results suggest that ethical climate and climatic forces are different constructs.

Other variables indicate that self-assessment is a fairly valid measure of their leadership ethics. Ethical leadership is positively related to ethical climate. The ethical climate is positively associated with collective OCBI and OCBO, but climate forces are not. Lastly, collectively they are significantly correlated with each other, which is in line with empirical findings that show a significant relationship between leadership climate (Ehrhart 2004; Williams and Anderson 1991).

\subsubsection{Relations Between Ethical Climate dan Etical Leadership}

The argument based analysis suggests that ethical leadership will be positively related to ethical climate. To test this hypothesis, a hierarchical regression analysis was performed. Ethical climate was regressed on a set of control variables in step 1 and ethical leadership in step 2. As reported in Table 4.4, ethical leadership significantly predicted ethical climate ( $=.10, \mathrm{p}<.01)$, providing support for the hypothesis.

Table 4.3: Index Goals-Target-Indicators of Civil Servants

\begin{tabular}{|l|c|}
\hline \multicolumn{1}{|c|}{ Goals - Target - Indicators } & Results \\
\hline Objective: The realization of a government that is accountable, innovative and transparent \\
\hline Index Good Governance & VERY SUCCESSFUL \\
\hline Index Reformasi Birokrasi & SUCCESSFUL \\
\hline Target: Increasing the accountability of government administration \\
\hline Opinion to BPK Audit & SUCCESSFUL \\
\hline SAKIP Kabupaten Value & SUCCESSFUL \\
\hline Status Result EKKPD & SUCCESSFUL \\
\hline Maturity SPIP Status & SUCCESSFUL \\
\hline Target: Increasing the quality of public services by utilizing Information Technology \\
\hline Index Civil Servant & SUCCESSFUL \\
\hline Indeks Government Technology System & SUCCESSFUL \\
\hline
\end{tabular}

Source :(Jitek, 2019) 
Table 4.4: Index Good Governance

\begin{tabular}{|c|c|c|c|c|c|c|c|c|c|c|c|}
\hline $\begin{array}{c}\text { Goal } \\
\text { Perfor } \\
\text { mance } \\
\text { Indicat } \\
\text { ors }\end{array}$ & $\begin{array}{c}\text { Base } \\
\text { line } \\
2015\end{array}$ & $\begin{array}{c}\text { Tar } \\
\text { get } \\
201 \\
6\end{array}$ & $\begin{array}{c}\text { realiz } \\
\text { ation } \\
2016\end{array}$ & $\begin{array}{c}\text { Tar } \\
\text { get } \\
201 \\
7\end{array}$ & $\begin{array}{l}\text { realiz } \\
\text { ation } \\
2017\end{array}$ & $\begin{array}{c}\text { Tar } \\
\text { get } \\
201 \\
8\end{array}$ & $\begin{array}{c}\text { Realiz } \\
\text { ation } \\
2018\end{array}$ & $\begin{array}{c}\text { Tar } \\
\text { get } \\
201 \\
9\end{array}$ & $\begin{array}{c}\text { Realiz } \\
\text { ation } \\
2019\end{array}$ & $\begin{array}{c}\text { Tar } \\
\text { get } \\
202 \\
0\end{array}$ & $\begin{array}{c}\text { Realiz } \\
\text { ation } \\
2020\end{array}$ \\
\hline $\begin{array}{c}\text { Index } \\
\text { Good } \\
\text { Govern } \\
\text { ance }\end{array}$ & $*)$ & $\begin{array}{c}63 \\
35\end{array}$ & 65,35 & $\begin{array}{c}66, \\
31\end{array}$ & 63,96 & $\begin{array}{c}67 \\
33\end{array}$ & 69,19 & $\begin{array}{l}69, \\
32\end{array}$ & 74,24 & $\begin{array}{c}69 \\
55\end{array}$ & 70,76 \\
\hline
\end{tabular}

source : (Jitek, 2019)

To understand the significant nature of moderation, Aiken and West's (1991) guidelines for interpreting interactions were used. All possible combinations of the effects of varying degrees of ethical climate and high and low levels of climatic strength collectively. In the objective-suggestion-indicator table the results of the success rate are shown in the very successful group only on the Good Governance index. The successful category includes the bureaucratic reform index, opinion on BPK audits, District SAKIP scores, EKPPD performance status, SPIP maturity level, public service index (IPP), and electronic-based government system index (SPBE). The objective classification expects the realization of an accountable, innovative and transparent governance. This objective expectation has been very successful in applying the Good Governance Index indicator. Recorded in the 2019 target and the realization in 2019 showed 69.32 and 74.24. However, the target of increasing the quality of public services in the use of information technology is still considered successful. In the use of information technology, it is necessary to improve through climate ethics. 


\section{Integrity Survey Results}

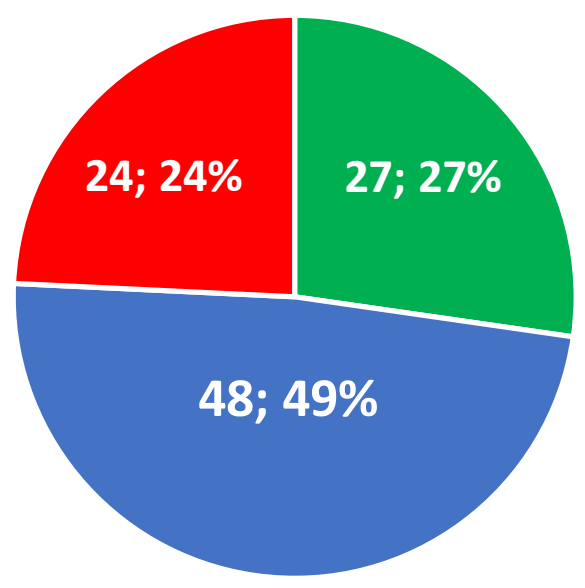

- Understand main duties, functions, and measure of success

- understand main duties and functions, misunderstand the measure of success

- Misunderstand main duties, functions, and measure of success

Figure 2: Integrity Surver Result (Jitek, 2019)

Appropriate implementation of comparative analysis in improving the ethical climate such as the construction of Public Service Malls, the Declaration of Integrity Zones towards Corruption Free Areas (WBK) and Clean and Serving Bureaucratic Areas (WBBM), as well as the implementation of the Working Culture Group (KBK) is able to encourage the achievement of indications that are according to the ethical climate. Every year the development of public service quality facilities will be achieved. Effective innovation, as well as giving opinions and ideas openly for employees in the organization will be fulfilled. Based on the Community Satisfaction Index with a very good score in 2019, there is still a need to increase diversification between groups. It means that every group of organizations that are joined must get the same equalization in terms of leadership policies, work methods, to touch the individual realm like gender.

Based on the analysis of the leadership power variable, hierarchically, the heads of offices in Sidoarjo District have a big role in encouraging climate innovation. From an internal perspective, the value of innovation is instilled in every activity of government and human resource development through policy implementation such as policy reform. The need for accountability and a humanist approach to unite all individual groups into one group. A substantial government process requires a process of understanding the obligations or duties and functions in each work implementation. The claim is that aggressiveness strategy needs to be used as a basic principle to combine innovation and substance. Understanding and contemporary use such as information and communication technology as a whole must be understood. The big criticism on this is the Sidoarjo District Government Civil Servants for 
the integrity of their positions hierarchically showing 24 out of 99 employees in response to not understanding the duties, functions, and indicators of employee success. 48 employees understand the function but it does not match the indicators. 27 employees have understood the duties and functions of the task implementation success.

The findings and discussion in this study indicate the importance of the role of ethical climate in public service employees in constructing attitudes and behavior of organizational members. The limitation in this study, by combining several previous studies according to the role of variables, shows that the ethical work climate greatly affects the capacity of organizational members. An important aspect is that the social identity of members of the organization will influence and imitate the behavior of other members. Formed hierarchically from members who are dominant or become leaders who have decreased influence. A management will encourage ethical behavior and ask for reciprocity from its employees to treat their employees fairly in order to run well.

The development of an ethical climate has become a criticism because of the shift in value and meaning in terms of an organization's capital. In this study, the friend who is most important in an ethical work climate has a direct relationship with his turnover. The level of coefficient in ethical norms from the practical point of view of an ethical work environment is positive for the organization.

Identify the ethical and procedural climate as a united perspective of several physical or psychological possessions within a group. It refers to a situation that is relative and sporadic in survival which determines individual traits. Identification involves the social aspects of an individual self-concept. The self-concept is based on a personal identity that becomes a person's class or ability and is known as social identity. Covering several classifications of social groups and individuals will classify themselves until they become the same social group. 


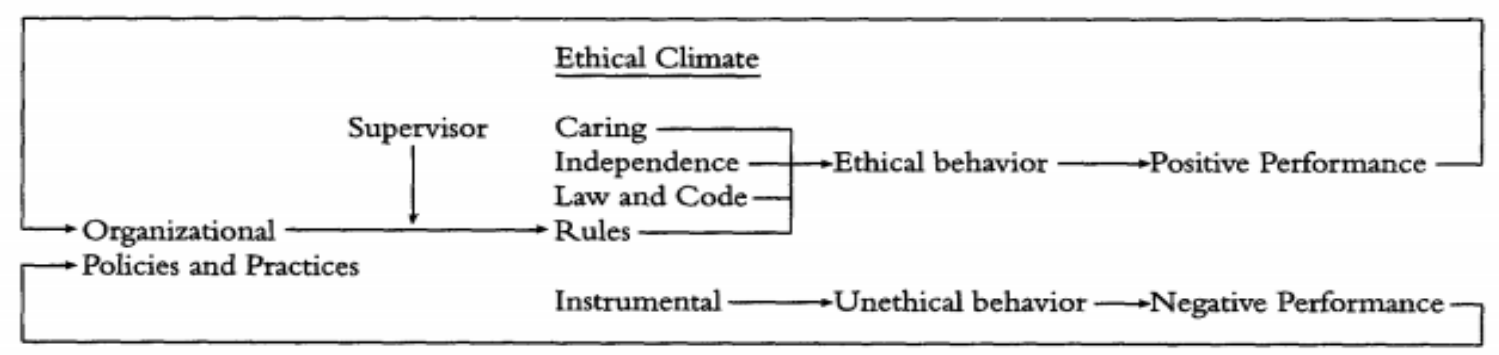

Fig. 3. Model of the relationship between ethical climate and ethical behavior.

Figure 3: Ethical Climate Process (Jitek, 2019)

This thinking ultimately provides a local construction in a cosmopolitan nature (DeConinck, 2011). The notion of identification organization is ultimately important for organization in a cosmopolitan. The concept of identity will help find the essence of individual identity by joining organizations that have similar characteristics. Such identification will be important in providing communication and dimensions in this ethical climate and forming interdependent legal norms.

Despite a great deal of research on ethical climate, relatively little is known about the relationship between ethical leadership and ethical strength. Highlighting the importance of ethical leadership in transmitting ethical values to employees and fostering an ethical climate within the company, there is a dearth of empirical evidence regarding the relationship between ethical leadership and ethical climate. In addition, little attention has been paid to those conditions that strengthen or weaken the link between ethical, climate outcomes and jobs. This study contributes to the business ethics literature by examining the relationship between ethical leadership and partner ethics and examining the moderate effects of climate forces on the relationship between ethical climate and ethical strength. The findings of this study have several ethical implications.

\section{V.CONCLUSION}

First, this study is one of the few attempts to conduct research on the relationship between ethical leadership, ethical climate, and the climate strength of civil servants in Sidoarjo District. Although many studies have examined the relationship between ethical climate and work outcomes, such analyzes have been mainly carried out at the individual level (Wimbush \& Shepard, 1994). However, given that the ethical climate at the organizational level builds employees' shared perceptions that reflect their company's ethical practices, policies, and procedures. The relationship between ethical climate and its related variables should be examined at the organizational level. Thus, by revealing the company- 
level dynamics between ethical leadership, ethical climate, climate forces, the current study extends the body of research on business ethics to the corporate level.

Second, the results of this study indicate the importance of ethical leadership in fostering an ethical climate, which supports the idea that ethical orientation is a key factor in promoting ethical behavior in an organization (Shin, 2012). Current results are also consistent with previous findings suggesting a positive relationship between ethical leadership and organizational climate. The positive relationship between ethical leadership and ethical climate can be explained by several theories, in addition to social learning theory, as previously mentioned. Institutional theory states that institutional factors influence the cognition and behavior of organizational members.

Among the various institutional factors, top management or are the main source of institutional structure because they can effectively manipulate the institutional environment. Based on this theory, it can be concluded that ethical leadership or top management shapes organizational climate by influencing employee perceptions and behavior. In addition, according to stewardship theory, organizational actors such as or top management bring their own moral values into the organization, causing the organization to exhibit more ethical behavior, which encourages a more ethical organizational climate (DeConinck, 2011). Consequently, by discussing the role of ethical leadership in fostering an ethical climate, the current study contributes to the literature on business ethics and leadership. 


\section{REFERENCES}

Brown, M. E., \& Treviño, L. K. (2006). Ethical leadership: A review and future directions. Leadership Quarterly. https://doi.org/10.1016/j.leaqua.2006.10.004

Bukhari, S. A. H. (2012). What is Comparative Study. SSRN Electronic Journal. https://doi.org/10.2139/ssrn.1962328

C. L., Benson, B. J., Nixon, L. J., \& Derstine, P. L. (2008). From the educational bench to the clinical bedside: translating the Dreyfus developmental model to the learning of clinical skills. Academic Medicine: Journal of the Association of, 761-767. http://doi.org/10.1097/ACM.0b013e31817eb632

DeConinck, J. B. (2011a). The effects of ethical climate on organizational identification, supervisory trust, and turnover among salespeople. Journal of Business Research, 64(6), 617-624. https://doi.org/10.1016/j.jbusres.2010.06.014

DeConinck, J. B. (2011b). The effects of ethical climate on organizational identification, supervisory trust, and turnover among salespeople. Journal of Business Research. https://doi.org/10.1016/j.jbusres.2010.06.014

Dunbar, K. N. (1998). Problem solving. A Companion to Cognitive Science, 289-298. Retrieved from http://psycnet.apa.org/psycinfo/1987-98523-000

Falzer, P. R., \& Garman, D. M. (2012). Evidence-based decision-making as a practice-based learning skill: a pilot study. Acad. Psychiatry, 36(2), 104-109. http://doi.org/10.1176/appi.ap.10050082, Carraccio

Feinstein, R. E., \& Yager, J. (2013). Advanced psychotherapy training: Psychotherapy scholars' track, and the apprenticeship model. Academic Psychiatry, 37(4), 248-253. http://doi.org/10.1176/appi.ap.12100174, Suddaby

Gobry, F. (1999). \{T $\}$ his is a title. $\{$ M $\}$ y Journal, 1, 120-130., Osment, S. E. (1980). T. A. of R. 1250-1550. ... and R. H. of L. M. and R. ... R. from http://scholar. google. $\mathrm{com} / \mathrm{scholar}$ ?hl=en\&btnG=Search\&q=intitle:THE+AGE+OF+REFORM+125.1550\#2\%5Cnhttp://scholar. google. com/scholar?hl=en\&btnG

Grojean, M. W., Resick, C. J., Dickson, M. W., \& Smith, D. B. (2004). Leaders, values, and 
organizational climate: Examining leadership strategies for establishing an organizational climate regarding ethics. In Journal of Business Ethics. https://doi.org/10.1007/s10551-004-1275-5

Jitek, A. (2019). Laporan Kinerja Pekerja Kabupaten Sidoarjo 2019. In Jurnal Ilmiah Teknosains (Vol. 2, Issue 1/Mei). https://doi.org/10.26877/jitek.v2i1/mei.1006

Keshav, S. (2007). How to Read a Paper. Work, 37(3), 83-84. http://doi.org/10.1145/1273445.1273458. (2007). The role of metacognition in social judgment. Social Psychology: Handbook of Basic Principles

Kimin, A. (2012). The focusing-oriented approach applied to couple therapy. A Thesis Submitted for the Degree of Ph.D in the School of Education and Lifelong Learning, University of East Anglia, (June), 553., Explicit, M. I. (n. d. ). T. knowledge M. I. E. A. T. for T. F., Williams, L. L., Levine, J. B.

Malhotra, S., \& Holtzheimer, P. (2004). The good-enough mentoring relationship. Acad. Psychiatry, 28(2), 111-115. http://doi.org/10.1176/appi.ap.28.2.111

Marenbon, J. (1998). R. H. of P. I. .. P. L. and N. Y. R. http://doi. org/10. 4324/978020306227.,

Ogbonna, E., \& Harris, L. C. (2000). Leadership style, organizational culture and performance: Empirical evidence from UK companies. International Journal of Human Resource Management. https://doi.org/10.1080/09585190050075114

Papadimitriou, A., \& Cai, Y. (2011). What drives the choice of mixed methods designs? An analysis of current higher education research publications. 7th Mixed Methods International Conference, (June)

Pole, N., \& Ablon, J. (2002). Ideal control mastery technique correlates with change in a single case. ... Theory, Research, Practice ..., 39(1), 88-96. http://doi.org/10.1037//0033-3204.39.1.88

Polikovsky, S., Kameda, Y., \& Ohta, Y. (2009). Facial micro-expressions recognition using high speed camera and 3D-gradient descriptor. 3rd International Conference on Imaging for Crime Detection and Prevention (ICDP 2009), (February), P. http://doi. org/10. 1049/ic. 2009. 024

P. L. and N. Y. R. http://doi. org/10. 4324/978020302947

R. O. Y. (2006). From the Editors : Academy of Management Journal, 49(4), 633-642.

Shanker, S. (2003). Philosophy of science, logic and mathematics in the twentieth century. 
Schneider, B., Salvaggio, A. N., \& Subirats, M. (2002). Climate strength: A new direction for climate research. Journal of Applied Psychology. https://doi.org/10.1037/00219010.87.2.220

S., Caprara, G., \& Fida, R. (2008). Longitudinal analysis of the role of perceived self-efficacy for self-regulated learning in academic continuance and achievement. ... of Educational ..., 100(3), 525-534. http://doi.org/10.1037/0022-0663.100.3.525

Shin, Y. (2012). CEO Ethical Leadership, Ethical Climate, Climate Strength, and Collective Organizational Citizenship Behavior. Journal of Business Ethics, 108(3), 299-312. https://doi.org/10.1007/s10551-011-1091-7

Sugiyono. (2012). Metode Penelitian Kuantitatif, Kualitatif dan R \& D.Bandung:Alfabeta. Metode Penelitian Kuantitatif, Kualitatif Dan $R \quad \& \quad$ D.Bandung:Alfabeta. https://doi.org/10.1017/CBO9781107415324.004

Thompson, M. (2011). Ontological shift or ontological drift? Reality claims, epistemological frameworks, and theory generation in organization studies. Academy of Management Review, 36(4), 754-773. http://doi.org/10.5465/amr.2010.0070

Tuma, J. M., \& Pratt, J. M. (1982). Clinical child psychology practice and training: A survey. Vldots of Clinical Child \& Adolescent Psychology, 137(August 2012), 37-41. http://doi.org/10.1037/a0022390

Wimbush, J. C., \& Shepard, J. M. (1994). Toward an understanding of ethical climate: Its relationship to ethical behavior and supervisory influence. Journal of Business Ethics. https://doi.org/10.1007/BF00871811

Xu, S., \& Rajlich, V. (2005). Dialog-based protocol: An empirical research method for cognitive activities in software engineering. 2005 International Symposium on Empirical Software Engineering, ISESE 2005, 397-406. http://doi.org/10.1109/ISESE.2005.1541848 